Persp. Teol. 33 (2001) 33-66

\title{
ÉTICA ECOLÓGICA: ANTROPOCENTRISMO OU BIOCENTRISMO?
}

José Roque Junges SJ

Os problemas ecológicos avolumam-se, ameaçando com uma total catástrofe o sistema terra. Buracos na camada de ozônio, aumento gradativo da temperatura, degelo das calotas polares, mutações climáticas, desertificação de imensas regiões, desaparecimento crescente de espécies vegetais e animais são alguns dos problemas que ameaçam o ecossistema terra.

Cresce, em contrapartida, a consciência e a sensibilidade ecológica. Florescem Organizações não-governamentais (ONGs) que lutam pela ecologia. Criam-se fundos para a preservação de ecossistemas e para a proteção de espécies ameaçadas de extinção. Surgem parques de preservação e proteção ambiental. A preocupação ecológica recebe embasamento jurídico através de leis em defesa do meio ambiente. Os governos são pressionados a assumirem políticas ecológicas que englobem o fator natureza em seus planejamentos.

Os problemas ecológicos não dependem de uma simples solução técnica, reclamam uma resposta ética. Requerem uma mudança de paradigma na vida pessoal, na convivência social, na produção de bens de consumo e, principalmente, no relacionamento com a natureza. Exigem uma mudança de rota na organização econômico-industrial e político-social da sociedade; de uma conversão das atitudes de consumo e de relacionamento com o ambiente natural e social. Tratase, no fundo, de uma mudança de mentalidade e visão do mundo. A 
preocupação ecológica não traz apenas novos problemas que exigem solução. Introduz um novo paradigma civilizacional. A ecologia levanta críticas radicais à racionalidade moderna e ao sistema econômico capitalista.

O debate ecológico levanta questões fundamentais para a ética. Discute o próprio ponto de partida e a abrangência dos sujeitos de consideração da ética. Assim foram surgindo enfoques antropocêntricos ou biocêntricos na discussão ética da ecologia. Uns partem do pressuposto de que o ser humano detém um protagonismo no mundo. Buscam a solução para os problemas ambientais na perspectiva do papel central do ser humano em relação à natureza. Outros defendem que o ser humano é apenas um elemento a mais no ecossistema da natureza, um elo ao lado de outros na cadeia de reprodução da vida. Por isso, o protagonismo pertence à vida. Para estes, a crise ecológica precisa ser equacionada numa perspectiva biocêntrica.

Desta maneira foram-se perfilando duas grandes tendências de ética ecológica que se excluem entre si. Uma que tem como ponto de partida o ser humano em sua postura ética. Defende que não existe ética sem antropocentrismo, pois somente o ser humano pode agir moralmente e tomar decisões. A ética ecológica é interpretada a partir do que comumente se entende por ética como saber da prática. A postura biocêntrica parte do ponto de vista da ecologia como conhecimento e prática de preservação do meio ambiente. Essa tendência compreende a ética a partir do paradigma da ecologia. Este paradigma pretende revolucionar a ética, porque supera a concentração antropocêntrica de toda a ética ocidental. Apresenta-se como a única postura coerente de defesa da natureza e preservação do meio ambiente. A primeira acentua a ética e a segunda a ecologia ao elaborarem sua proposta de ética ecológica.

Antropocentrismo ou biocentrismo? ${ }^{1}$ É possível sair deste impasse da ética ecológica? Existem questões de fundo não explicitadas, dificultando o debate. É um fato que a ecologia como paradigma veio para ficar e significa uma mudança de mentalidade e visão de mundo. Qual é o tipo de ética apropriado para a discussão ecológica? Quando se fala de que é necessário superar a postura antropocêntrica, de que ser humano se está falando?

Outra dificuldade do debate é o próprio contexto em que se desenvolve: Primeiro Mundo moderno e abastado. Como aconteceria essa discussão num contexto de Terceiro Mundo excluído, onde imperam

'F. RICKEN, “Anthropozentrismus oder Biozentrismus? Begründungsprobleme der ökologischen Ethik", Theologie und Philosophie 62 (1987) 1-21. 
a fome, a injustiça e a opressão? A controvérsia apareceria sob nova luz, ajudando a vencer o impasse. A partir da pobreza e da injustiça, humanidade e vida não se opõem. A preocupação ecológica precisa ser equacionada com a construção de uma sociedade justa e igualitária, onde a vida, em sentido amplo, é valorizada e preservada.

\section{Tendências éticas presentes na discussão ecológica}

A preocupação e a sensibilidade ecológicas surgiram como reação a uma mentalidade predatória diante da natureza. Os recursos naturais estão à disposição do desfrute ilimitado do ser humano. $O$ dever moral é utilizar para proveito imediato e o mais rapidamente possível o máximo de recursos naturais disponíveis. É a ética que acompanha e justifica a conquista de terras selvagens e a sua colonização e exploração em vista do lucro e do enriquecimento. É a mentalidade que inspirou a ocupação do território brasileiro desde a chegada dos portugueses e continua até os dias de hoje. A busca de novas terras para a mineração e a agricultura chegou aos últimos rincões do Brasil durante os últimos dois séculos, motivada pela ideologia do progresso, explorando os recursos naturais pela técnica e dominando a natureza para construção da civilização. Esse processo sócioeconômico e cultural foi causado e motivado pelo capitalismo. Os efeitos de injustiça social e destruição da natureza estão patentes e despertam reações no sentido de uma mudança de paradigma.

O ponto de partida da ideologia do progresso é o mito da superabundância da natureza; a crença no caráter ilimitado dos seus recursos e a surrogabilidade daqueles exauriveis; a total confiança na produção intensiva, no incremento do consumo e no poder da técnica para resolver os problemas ambientais. O ser humano concebe-se como dono absoluto dos recursos naturais e como Prometeu na aventura de dominar a natureza entendida como caos no qual é necessário colocar ordem. Mas essa ordem imposta mostrou-se como total desordem, porque desestruturou o equilíbrio ambiental responsável pela reprodução da vida. Esse antropocentrismo exagerado expressa-se como ética do chauvinismo humano.

A discussão ética no âmbito da ecologia surgiu como resposta a esse contexto e como reação a uma mentalidade predatória da natureza. As posiçōes subdividiram-se em duas tendências: uma mais mitigada, caracterizada por um antropocentrismo débil, e outra mais radical, inspirada por um ecologismo biocentrista².

\footnotetext{
2 Para um conhecimento mais aprofundado dessas tendências, cf. S. BARTOLOMMEI, "Etica e natura. Una 'rivoluzione copernicana", in Etica, Bari: Laterza, 1995. J. B. CALL.ICOTT, "Environnement. Éthique de l'environnement", in M. CANTOSPERBER (Ed.), Dictionnaire d'ithique et de philosophite morale, Paris: PUF, 1997, 2" ed, pp. 498-501.
} 


\section{Antropocentrismo débil ou mitigado}

Diferentemente de sua versão exagerada e chovinista, admite a existência de deveres humanos, ao menos indiretos, em relação à natureza ou de uma responsabilidade dos humanos pelos recursos naturais diante das gerações futuras. Defende a determinação de limites e regras para a intervenção na natureza e o uso de seus recursos para o bem dos próprios seres humanos. Por isso, os critérios para as restrições são os interesses, as necessidades ou preferências humanas e não tanto a natureza em seu equilíbrio e harmonia.

De acordo com o tipo de interesses humanos podemos ter éticas de conservação e éticas de preservação da natureza. As primeiras estão interessadas em conservar os recursos naturais, porque eles são limitados e as gerações futuras também tem direito a eles. A natureza deve ser protegida para satisfazer as necessidades materiais do ser humano. As segundas querem preservar a natureza para o crescimento humano e interiorização espiritual. Deve ser tutelada contra a intervenção destrutiva do homem para satisfazer as necessidades humanas que ultrapassarem os interesses materiais, ideais de aprofundamento humano e espiritual.

\section{1 Éticas conservacionistas}

As éticas de conservação podem assumir o modelo do "bote salvavidas" de G. Hardin ${ }^{3}$. Diante da crise ambiental compara a terra a um mar tempestuoso com botes salva-vidas. Os países ricos são botes com poucas pessoas e os países pobres, botes com sobrecarga de gente, querendo embarcar nos botes ricos. Esses não têm condições de acolher a sobrecarga, porque o bote irá afundar e todos perecerão. Por isso, é necessário tomar medidas coercitivas que limitem as nações ricas em seu consumo e as nações pobres em sua população. Tratase de medidas drásticas que atingem a todos. É uma proposta que tenta pensar a humanidade como um todo, visando a sobrevivência da espécie humana. Não toma em consideração a preservação do ecossistema da terra. Busca a sobrevivência da civilização e não da biosfera natural.

\footnotetext{
${ }^{3}$ G. HARDIN, "Living on a Lifeboat", Bioscience 24 (1974) 561-568; O mesmo aparece em trabalhos anteriores do mesmo autor: "The Tragedy of the Commons", Science 162 (1968) 1243-1248; Exploring New Ethics for Survival. New Yok: Penguin Books, 1973; The limits of Altruism: An Ecologist's View of Survival, Bloomington/London: Indiana University Press, 1977; Promethean Ethics: Living with Death, Competition and Triage, Seattle: Washington University Press, 1980.
} 
Outro modelo é o da "nave espacial" de K. Boulding ${ }^{4}$. Considera a terra como um sistema fechado, finito e auto-reprodutor. A terra é uma nave espacial, onde natureza e seres humanos estão intimamente relacionados. Um incidente na nave põe todos em perigo. Não se pode sacrificar a estabilidade e integridade do nosso meio de transporte, a nave terra, com a satisfação de interesses privados. Por isso, é necessário criar as condições para chegar a consensos que submetem as preferências dos indivíduos aos interesses do ecossistema terra. Diferente da primeira que é deontológica, esta é utilitarista porque tenta maximizar os benefícios, em parte empíricos, mas também valorativoespirituais.

\section{2. Éticas preservacionistas}

As éticas de preservação apontam para valores não materiais da natureza. A natureza pode ter antes de mais nada um valor científico, pois fornece conhecimentos de valor inestimável para a pesquisa da verdade, para encontrar a natureza ideal ou a excelência moral a perseguir, para fornecer normas ideais de comportamento. $O$ estudo da natureza possibilita a formulação de uma ética natural.

A natureza tem além disso um valor estético-espiritual, porque transforma o ser humano, ocasionando experiências de valor e sentido para a vida, de prazer e fruição estética, de recolhimento espiritual, de pacificação interior, de formação pedagógica, de sensibilização ecológica.

As éticas que privilegiam significados ideais da natureza não se preocupam tanto com normas, mas pelo tipo de pessoa que se quer ser ou da personalidade moral que se quer fazer suscitar. Preocupam-se com contextos embebidos de valores, com um ethos prático formador do caráter moral da pessoa. Trata-se, em última análise, de éticas da virtude.

Um primeiro modelo vê a importância da proteção da natureza em vista da formação e consolidação da identidade civil e cultural de um grupo nacional ${ }^{5}$. Essa identidade não depende apenas de iniciativas econômicas e políticas, mas de símbolos que se escolhem e abraçam. Símbolos podem ser tradições culturais, jurídicas e políticas, mas tam-

\footnotetext{
${ }^{4}$ K. BOULDING, Human Values on the Spaceship Earth, New York: Council of Churches, 1966; "The Economics of Coming Spaceship Earth", in H. JARRET (Ed.), Environmental Quality in a Growing Economy, Baltimore: Johns Hopkins University Press, 1969. ${ }^{5} \mathrm{M}$. SAGOFF, "On Preserving the Nature Environment", The Yale Law Journal 84 (1974) 205-267; The Economy of the Earth, Cambridge: Cambridge University Press, 1988, pp. 124-145.
} 
bém elementos da natureza. Uma nação pode identificar-se por uma montanha, um rio, uma floresta, uma árvore, um animal etc. O tipo de configuração natural e geográfica de um país faz parte do sistema de orientação simbólica de um povo. Por isso é importante preservar a natureza e criar atitudes de defesa e apreço em relação a ela.

Outro modelo parte da importância do conhecimento da natureza para a formação do caráter moral dos seres humanos. Conhecer a natureza não é apenas um fato puramente intelectual, mas leva a uma redefinição em relação a si mesmo e ao mundo. Trata-se de um valor transformativo da natureza e não tanto de seu valor intrínseco ${ }^{6}$. Por valor transformativo entende-se a capacidade do conhecimento da natureza de corrigir preferências irreflexas e imediatas em decisões esclarecidas. A ecologia como ciência é um exemplo dessa capacidade de chegar a decisões adequadas ao meio ambiente, porque vê o ser humano fazendo parte de uma comunidade biótica e dependendo dela para sua sobrevivência. Ensina a conhecer os níveis de interdependência dos diferentes elementos de um ecossistema, preservando o equilibrio e prevendo conseqüências de uma intervenção humana. Assim o conhecimento ecológico ajuda a esclarecer preferências e a fundamentar decisões éticas.

Um terceiro modelo privilegia a fruição das belezas naturais, sublinhando a conexão entre a preservação do belo natural e o aperfeiçoamento do caráter moral ${ }^{7}$. Defende um valor intrínseco da natureza e não apenas simbólico. A harmonia e o equilíbrio das belezas naturais devem ser protegidos por si mesmos e não por seu valor instrumental. Embora não sendo experimentado esteticamente, merece tutela moral enquanto tal. Essa preservação possibilita mais qualidade humana aos seres humanos. Faz uma analogia entre o belo artístico e o belo natural na criação de um mundo melhor e na elevação moral e espiritual dos seres dotados de consciência.

O último modelo prega uma mutação da Gestalt e uma ultrapassagem da ética. Não pretende elevar e estender a sensibilidade moral do ser humano, mas modificar o modo de viver e sentir em relação ao meio ambiente. Não visa chegar a um ser humano melhor e moralmente superior, mas a um ser humano novo e diferente que tem com a natureza uma relação emotivo-afetiva, mais do que ético-civil, éticointelectual ou ético-estético, como acontece com as anteriores. Por isso, designa-se como ecologia profunda (Deep Ecology) em relação às

'B. G. NORTON, Why Preserve Naturnl Varicty? Princeton: Princeton University Press, 1987, pp. 185-213.

'E. C. HARGROVE, Fountations of Environmental Ethics, Englewood Cliffs: Prentice Hâll, 1989. 
demais, tidas como superficiais. É defendida pelo filósofo norueguês Arne Naess ${ }^{8}$. Trata-se de uma superação da ética e uma reestruturação dos paradigmas cognitivos, comportamentais e afetivos com vistas a um alargamento e mutação da sensibilidade humana.

A ecologia profunda defende que não se pode reduzir a crise ambiental a um puro conflito ético, pois se trata da necessidade da mudança de paradigmas conceituais e de Gestalt na percepção e configuração do mundo. É necessário uma mutação no modo de perceber o mundo e de captar o lugar do ser humano no mundo. Portanto, não se trata de uma ética no sentido de elaboração de normas e imperativos, mas de uma total conversão e excelência moral. O modelo de ser humano "egóico", compreendido como indivíduo isolado e separado do mundo, transformando a natureza em objeto que se encontra ao seu dispor, cria patologias ambientais, correspondentes a patologias psicológicas, pedagógicas e sociais. É necessário superar a concepção do ser humano como espécie dominante e separada do mundo, espoliando-se do seu isolamento e colocando-se no ponto de vista de todos. Trata-se de assumir o ponto de vista holístico, adotando formas transpessoais em suas atitudes frente à natureza. Assim surge um ser humano "ecóico" em vez de "egóico" que se compreende essencialmente como um ser em relação.

O modelo de ecologia profunda preocupa-se com uma mutação radical do paradigma de percepção do ser humano. Por isso, ainda se encontra entre as éticas ecológicas que tem o ser humano como ponto de partida. Mas, ao mesmo tempo, ela abre para o seguinte conjunto de éticas que privilegiam a vida como enfoque para a construção do discurso ético.

\section{Biocentrismo}

As tendências antropocêntricas defendem a responsabilidade do ser humano para com a natureza (for the nature), enquanto que as biocêntricas, deveres diante da natureza (to the nature). Em outras palavras, a natureza é sujeita de direitos. Falam de deveres diretos e não apenas indiretos para com o meio ambiente. São críticos das posiçōes antropocêntricas, postulando um valor intrínseco para a natureza e rejeitando uma diferença de tratamento entre seres humanos e não humanos.

Existem dois tipos de tendências éticas anti-antropocêntricas: umas que privilegiam entidades individuais (biocentrismo mitigado), outras

A. NAESS, Ecology, Community and Lifestyle, Cambridge: Cambridge University Press, 1989. 
que acentuam totalidades e processos naturais irredutíveis aos seus componentes (biocentrismo global).

\subsection{Biocentrismo mitigado}

Defende que entidades individuais detentoras de vida e de sensações merecem a tutela moral, porque são sujeitos de direitos. O primeiro modelo é defendido por T. Regan'. O ponto de partida é que todo sujeito de vida merece consideração moral. Sujeito de vida é aquele ser que possui um "ponto de vista" sobre sua própria vida, em base à qual a vida em suas sensações pode aparecer melhor ou pior para quem a vive, independente dos significados de utilidade para os outros. Quem possui esse ponto de vista é depositário de valor inerente e titular de direitos inalienáveis, não podendo sofrer alterações e interferências no curso da sua vida. Sujeitos de vida exigem respeito por razão de justiça e não por motivos de compaixão. Não podem ser reduzidos a puros objetos. Ter um ponto de vista significa, para Regan, possuir identidade psicofísica, ter capacidade de desejos e atuar com objetivo. Nessa categoria entram os mamíferos de um ano de vida.

Outro modelo é o da capacidade de sentir dor e prazer, patrocinado por P. Singer ${ }^{10}$. Defende que o fato de experimentar sofrimento é digno de consideração moral. É imoral infligir sofrimento em todo ser vivo que sente dor. O que determina que um ser seja digno de consideração moral não é, segundo Singer, sua capacidade de falar, de ter consciência e razão ou outras competências cognitivas superiores, mas apenas a capacidade de sentir dor e prazer. Aplica-se aqui a moral da regra de ouro: "tratar os outros como gostaria de ser tratado". O sofrimento de qualquer ser deve ser avaliado à luz do próprio sofrimento. Trata-se de estender a proteção contra o sofrimento deliberadamente provocado aos mamíferos superiores.

Tanto T. Regan quanto P. Singer estão engajados na "Animal Liberation". O primeiro reporta-se à teoria dos direitos, concebendo os animais superiores como sujeitos de vida, detentores de autonomia e identidade; o segundo, ao contrário, inspira-se no utilitarismo clássico, vendo-os como receptáculos de sensações de prazer e dor. A aplicação da categoria de sujeitos morais e, respectivamente, de direitos fundamentais aos animais superiores é problemática como veremos mais abaixo.

9 T. REGAN, The case for Animal Rights, Los Angeles: The Regents of the University of California, 1983.

10 P. SINGER, Animal Liberation, London: Jonathan Cape, 1976; Ética prática, São Paulo: Martins Fontes, 1994. 
O terceiro modelo veiculado por P. W. Taylor ${ }^{11}$ amplia a consideração moral, incluindo os seres biologicamente organizados e não apenas os que têm sensações e preferências de bem estar. Merecem tutela todos os centros teleológicos de vida. Refere-se a organismos individuais viventes que têm certas características (células, funcionamento, relações com outros organismos) e ritmos próprios de crescimento e desenvolvimento. A posição de Taylor é radicalmente biocêntrica, tutelando todo organismo vivente não apenas enquanto centro teleológico de vida, mas como ser particular em sua individualidade e irrepetibilidade. Trata-se de dar igual consideração a todos os viventes na sua insubstituibilidade e unicidade e tutelar cada ser vivo como fim em si mesmo e não como meio. Taylor não chega a uma posição mais global, protegendo ecossistemas e a biosfera como um todo. Essa posição individualizada dos seres vivos é totalmente inviável e problemática para uma visão ecológica.

\subsection{Biocentrismo Global}

Essas tendências são fortemente anti-antropocêntricas e holísticas, não tentando fazer analogias entre humanos e não humanos para defender suas posições como acontece com o biocentrismo mitigado, quando este fala de sujeito moral ou de direitos de seres individuais. Parte de conhecimentos científicos da ecologia, do reconhecimento da natureza como um conjunto interdependente e do lugar do ser humano nesse conjunto para chegar a normas em relação ao meio ambiente. Defende que são merecedoras de consideração moral não tanto entidades individuais, mas os conjuntos sistêmicos (ecossistemas, biosfera, cadeias alimentares, fluxos energéticos).

Um primeiro modelo valoriza a vida enquanto tal, não como propriedade de entidades individuais, mas de totalidades complexas e estruturais e de processos bióticos. A vida é um processo de tipo global não redutível ao valor dos organismos singulares. A vida dos indivíduos depende dos fatores que possibilitam a reprodução da vida nos ecossistemas. Nesse conjunto interdependente de condições bióticas pulsa a vida através de inter-relações que equilibram os processos vitais. Os próprios ecossistemas detém vida pelo equilibrio de suas cadeias alimentares e fluxos energéticos.

Esse modelo do valor da vida inspira-se na "Ética do respeito à vida" do teólogo luterano e missionário na África, Albert Schweitzer ${ }^{12}$.

"P. W. TAYLOR, Respect for Nature: A Theory of Environmental Ethics, Princeton: Princeton University Press, 1986.

12 A. SCHWEITZER, Kultur und Ethik, 1958. 
Ele defende uma moral de solidariedade e de simpatia a toda forma de vida (humana ou não humana) na qual se encontra a "vontade "de viver". Esta pulsa em toda terra, infundindo a todo ser vivente uma aura de sacralidade. A "vontade de viver" é um continuum indiferenciado no qual não existem distinções entre formas mais altas e mais baixas de vida. O princípio do respeito à vida (Prinzip der Ehrfurcht vor dem Leben) expressa-se numa frase que se tornou paradigmática da ética de Schweitzer: "Eu sou vida que quer viver em meio à vida que quer viver" ("Ich bin Leben das leben will inmitten von Leben das leben will"). A vida é o dinamismo sagrado que pulsa em toda natureza. Por isso, tudo o que tem vida é moralmente relevante e deve ser respeitado. Schweitzer defende um tipo de ética da sacralidade e respeito à vida comparável às religiões hinduístas.

Johnson e Goodpaster apresentam uma versão secularizada da ética da sacralidade da vida de Schweitzer. O discurso ético tem uma inspiração e fundamentação mais biológica e ecológica. Substituem a "vontade de viver" pelo "interesse de bem estar" dos seres vivos ${ }^{13}$. Por serem entidades de bem estar, os seres vivos não dependem de um juízo de valor humano, mas de um dado constitutivo da realidade vivente. Interesse de bem estar tem aquelas realidades com unidade orgânica e auto-identidade. Engloba tudo aquilo caracterizado por processos auto-referenciais ou autocentrados e regulado por esquemas homeostáticos de ação e retroação. Interesses de bem estar não são algo que se tem, mas se é. Deixar de ter interesses de bem estar é deixar de ser, pois o que é funcional para a existência do ser vivo faz parte de sua natureza. A vida é o próprio funcionamento. Os seres viventes têm interesse em manter-se no processo biológico da vida em desenvolvimento, pois ele faz parte da sua natureza. Têm interesses de bem estar tanto as entidades quanto os sistemas.

Outro modelo de Ética biocêntrica global é a assim chamada "Ética da Terra" (Land Ethic), proposta em 1949, pelo americano Aldo Leopold, estudioso de ecologia da Universidade de Wisconsin ${ }^{14}$. Ele era um estudioso de biologia e, por isso, mais influenciado por Darwin do que por Kant e Bentham, inspiradores dos principais paradigmas éticos modernos. O paradigma biológico de Leopold parte do altruísmo e não do egoísmo. Os seres humanos são ligados aos seus seme-

${ }^{3}$ L. E. JOHNSON, A Morally Deep World: An Essay on Moral Significance and Environmental Ethics, New York: Cambridge University Press, 1992; K. E. GOODPASTER, "On Being Morally Considerable", Journal of Philosophy 75 (1978) 308-325; Idem, "From. Egoism to Environmentalism", in K. E. GOODPASTER / K. M. SAYRE, Ethics and Problems of the 21st Century, Notre Dame: University of Notre Dame Press, 1979, pp. 21-35.

${ }^{14}$ A. LEOPOLD, A Sand County Almanac and Sketches Here and There (1949), New York: Oxford University Press, 1968. 
lhantes por sentimentos de simpatia que Hume e Smith chamaram de sentimentos morais. Se isto vale para uma comunidade humana, podese despertar esses mesmos sentimentos em relação a uma comunidade ecológica. Esse é o ponto de partida da "Ética da Terra", de A. Leopold. Para ele, qualquer ética desenvolvida até agora apoia-se sobre uma única premissa: o indivíduo como membro de uma comunidade de partes independentes. A ecologia acrescenta que é necessário alargar os confins da comunidade para incluir solo, água, plantas, animais e, coletivamente, a terra.

Para Leopold, algo é moralmente justo, quando tende a preservar a integridade, estabilidade e beleza da comunidade biótica. Errado é fazer algo em direção contrária. Sua ética está fundada no sentimento e na comunidade, tendo uma perspectiva mais holística do que os paradigmas modernos. Deriva valores éticos ambientais de fatos conhecidos da ecologia, biologia evolutiva e da psicologia humana. Partindo de Hume, A. Leopold afirma que o conhecimento de fatos pode produzir dois tipos de conduta: suscitando paixão, respeito, amor ou descobrindo a ligação entre causa e efeito que avalia qualquer paixão.

A biologia levou a humanidade ao conhecimento do fato de que todas as formas de vida e os seres humanos descendem de antepassados comuns. A biologia evolutiva mostrou o parentesco comum de todos os viajantes da aventura da vida. O conhecimento deste fato suscita amor e respeito como quando conhecemos parentes. A biologia ecológica faz tomar consciência da existência de comunidades bióticas às quais estamos ligados como membros, ligações não menos estreitas do que com comunidades humanas. Esse conhecimento desperta sentimentos de lealdade e "patriotismo", semelhantes aos que experimentamos em relação a conjuntos sociais e nacionais.

Os pressupostos da ética de A. Leopold são o conhecimento de que a terra é uma comunidade biótica, o conseqüente despertar em relação a ela de sentimentos de amor e respeito e a criação, a partir desse conhecimento e sentimentos, de uma cultura da terra.

A Land Ethic, de A. Leopold, inspirou outros modelos. O primeiro é a ética ecológica de $\mathrm{H}$. Rolston $\mathrm{III}^{15}$ que parte de um pressuposto, comum dessas tendências, de que o ser humano é apenas uma parte de um conjunto biótico e de que não existem partes mais relevantes do ponto de vista ecológico. A natureza é uma trama de inter-relações onde cada ser é apenas um anel de uma cadeia ininterrupta de maté-

15 H. ROLSTON III, Philosophy Gone Wild: Essays in Environmental Ethics, Buffalo: Prometheus Books, 1986: Idem, Environmental Ethics: Duties to and Values in Nature, Philadelphia: Temple University Press, 1988. 
ria, energia e informação em função da estabilidade e integridade da própria cadeia da vida. Para Rolston o critério ético são os interesses de bem estar (estabilidade e equilíbrio) de uma comunidade biótica. Nesse sentido a ética ambiental tem que ser uma ética ecológica ou uma ética da terra. O que interessa não é tanto a vida em si, mas a configuração ecológica do ambiente que permite a reprodução da vida. As entidades individuais estão subordinadas ao bem estar da comunidade biótica. Para isto, é necessário respeitar as leis inscritas nos ecossistemas naturais e explicitadas pela ecologia. Assim, a ética ambiental não é criação humana, mas sistematização de normas inscritas na natureza. A tarefa dos seres humanos é dar-se conta dessas normas e adequar o seu comportamento aos equilíbrios homeostáticos e aos fluxos energéticos da ecosfera.

Outro modelo é a ética bioempática de J. B. Callicott ${ }^{16}$. Reproduz a ética de A. Leopold. Para ele, a ética não é mais que o instinto de defesa da comunidade e baseia-se nos sentimentos de simpatia radicados no ser humano. Nesse sentido, a ética é um estratagema adaptativo para limitar a liberdade de ação dos seres humanos em função do êxito reprodutivo da espécie humana. Na luta pela sobrevivência, os confins da convivência restringem-se à família, sociedade e nação. É necessário alargar os limites até englobar a comunidade biótica. Trata-se de fazer uma grande aliança contra o perigo de aniquilação do planeta terra.

Os seres humanos estão biologicamente constringidos a assumir a nova imagem da terra caracterizada pela interdependência biótica de todos os seres viventes e não viventes e pela pertença a um destino comum identificado com a biosfera. Assim acontece uma evolução natural dos sentimentos morais dos seres humanos, porque passam do mero cuidado dos humanos à inclusão paritária das espécies nãohumanas e das comunidades bióticas. Esses sentimentos de bioempatia significarão uma revolução cultural. Por isso, a Land Ethic aproximase da Deep Ecology, porque prega uma mutação prática da sensibilidade humana e aponta os limites dos processos tradicionais de identificação humana restritos ao mais próximo. É necessário englobar novos elementos de identificação oriundos da sensibilidade ecológica. A diferença entre as duas éticas ecológicas é que a primeira tenta construir uma ética em base científica e a segunda defende uma superação da ética através de uma mutação da percepção.

Essa exposição bastante detalhada das diversas tendências de ética ecológica foi necessária para tomar o pulso da discussão, praticamente

${ }^{16} \mathrm{~J}$. B. CALLICOTT, In defense of the Land Ethic: Essays in Environmental Philosophy, New York: State of New York University Press, 1989. 
desconhecida em nosso contexto, e para dar-se conta dos problemas nela implicados. Como em qualquer debate moral, o conflito entre posicionamentos que privilegiam o ponto de vista do ser humano (antropocentrismo mitigado), das entidades vivas individuais (biocentrismo atomizado) ou das comunidades bióticas (ecocentrismo holístico) depende de premissas antropológicas e éticas e de um contexto cultural. Para poder situar-se nesse emaranhado de idéias e posições, é preciso explicitar pressupostos e paradigmas. Depois desse esclarecimento será possível apresentar algumas teses que apontem para as balizas de uma ética ambiental.

\section{Paradigma ecológico}

A crise ecológica não significa apenas o surgimento de problemas ambientais exigindo resposta, mas a emergência da necessidade de um novo paradigma de percepção do mundo e da natureza em especial. A solução não está em mudanças que apenas procuram obviar as conseqüências funestas do uso de uma técnica invasiva dos equilíbrios homeostáticos da natureza. Impõe-se uma mutação cultural que supere a visão redutiva e alcance um enfoque mais global da natureza. Trata-se da passagem de um redutivismo científico-metodológico a uma cuitura sistêmica do ambiente.

De uma época de total equilibrio e dependência do ser humano da natureza no paleolítico, passa-se a um gradativo distanciamento iniciado com a revolução agrícola do neolítico e chegando ao seu auge na revolução industrial inaugurada no século XVIII. De um gerenciamento e domesticação dos processos naturais para defender-se da inclemência da natureza e construir um habitat humano em total harmonia com o sistema natural passou-se a um total controle e domínio sobre os recursos naturais pelo desenvolvimento do método científico e a difusão das tecnologias, dando origem à civilização industrial povoada de luzes e sombras.

É inegável que a industrialização melhorou significativamente a vida dos seres humanos, mas provocou igualmente efeitos desastrosos que agora ameaçam aqueles que ela própria procurou beneficiar. As conseqüências negativas não são fruto da própria ciência e técnica, mas da falta de uma cultura mais sistêmica do ambiente e de um igualitarismo em relação aos seres viventes presentes nas civilizações rurais. A civilização industrial provocou a acentuação do dualismo entre ser humano e natureza, a exploração dos recursos naturais a serviço das crescentes necessidades humanas, o desenvolvimento de tecnologias com impacto sobre o ambiente, o uso e a exploração de novas fontes de energia, o aumento exponencial da população, a complexificação dos sistemas so- 
ciais pelo surgimento de classes sociais e pelo desaparecimento de modos alternativos de vida através da massificação cultural. Tudo isto levou a um dissídio crescente entre a sociedade humana e o meio ambiente, a divisões e discriminações na sociedade humana.

Pode-se apontar vários indícios desse redutivismo no modo de relacionar-se com a natureza. Os métodos de análise e intervenção no ambiente processados pela ciência e a técnica são inadequados, porque o conhecimento foi dividido em especialidades, faltando um saber do conjunto. A ecologia justamente surgiu para responder a essa necessidade. Operou-se uma fragmentação da realidade correspondente à sociedade fragmentada em classes, orientada à produção econômica e dividida em especialidades e trabalhos.

A tecnologia teve um desenvolvimento crescente sem atender às suas repercussões sobre o ambiente. As conseqüências são preocupantes e a opinião pública está apenas acordando para elas. Aconteceu igualmente uma nítida separação entre ciências naturais e humanas, entre matéria e espírito, entre ciência e fé, entre economia e ética, entre indivíduo e sociedade. Essa separação corresponde ao processo de especialização e positivização do conhecimento científico.

Aconteceu um aumento gradativo da população, levando a uma maior procura de bens extraídos da natureza e a um incremento consequiente da tecnologia. Assim, as potencialidades dos mecanismos naturais de adaptação e equilíbrio foram superadas e a própria adaptação cultural foi quebrada, provocando resultados desastrosos.

Na história da percepção da realidade da natureza e do ambiente, a sociedade passou substancialmente por dois momentos. Sob o estímulo da revolução científica e do seu redutivismo científico, o caráter orgânico da percepção pré-científica das sociedades tradicionais foi destruído. Sob o estímulo da pesquisa em ecologia, a ciência dos sistemas e o enfoque estruturalista repropuseram uma visão integral da realidade natural e social. Estamos diante da emergência de um novo paradigma mais holístico inspirado pela ecologia que pretende superar a visão limitada e estreita da racionalidade instrumental moderna. Impõe-se a urgência de uma racionalidade dialógica, bioempática e holística para acercar-se da realidade natural e social, para fazer frente aos desafios ambientais.

O paradigma ecológico significa uma crítica radical à autonomia solipsista da modernidade e uma proposta de percepção da realidade em suas inter-relações e não como pura soma de entidades individuais. Amplia a pura perspectiva intersubjetiva dos humanos e tenta incluir também a consideração das interdependências e interligações com os seres vivos e com os ecossistemas e a biosfera. 
Um sistema vivente (ecossistema) não é a pura justaposição de seres vivos e fatores que possibilitam a vida, mas um complexo de interações de dinamismos vitais. A Terra (ecosfera) é um ambiente diversificado e variado de subsistemas: litosfera, hidrosfera, atmosfera e biosfera. Pela fotossíntese das plantas, pela alimentação e evacuação dos animais e pela ação decompositora dos microorganismos instauram-se complicados sistemas de relações entre esses subsistemas. A matéria inorgânica, o calor e a luz solar são englobados nos processos da vida através de ciclos biogeoquímicos e de fluxos de energia autoregulados para impedir e obviar perturbações no equilibrio.

O dinamismo vital é essencialmente absorção e consumo de energia. As plantas armazenam energia que vem do sol, os animais comem ervas ou outros animais, acontecendo uma transferência e consumo de energia. Os microorganismos decompõem os seres vivos que morrem, possibilitando a liberação de substâncias químicas (nitratos e fosfatos) que, por sua vez, são de novo absorvidos pelas plantas e recomeça o ciclo. A lenta evolução desse processo global da vida deu origem à biosfera e possibilitou o surgimento de suborganizações funcionais identificadas com as diferentes comunidades bióticas.

O processo da vida é formado por substâncias químicas nutrientes que, continuamente, circulam nos seres vivos pela transformação ou acumulação; pela energia que entra e é processada pela fotossíntese das plantas, transferindo-se para os animais pela alimentação e dispersando-se em energia calorífera; e, finalmente, pelos seres viventes que são a chave de circulação de energia vital nas comunidades bióticas.

O ser humano é um elo desse processo. Está inserido no ambiente físico, químico e biológico, implicado como qualquer outro vivente nos processos de circulação das substâncias nutrientes, de fluxo de energia e de manutenção do equilíbrio. Mas o ser humano, diferente dos outros seres, desenvolveu um confronto cultural com o seu quadro vital, enfraquecendo sua relação e dependência do ambiente biótico. Pela cultura, o ser humano cria um gerenciamento do ambiente, conferindo-lhe identidade própria, em harmonia com o ecossistema natural ou comprometendo dramaticamente o seu funcionamento.

As sociedades humanas desenvolveram a capacidade de intervir no ambiente e nos processos naturais segundo objetivos e modelos próprios. Por isso, elas têm a responsabilidade de não destruir a qualidade do ambiente em que vivem e agem no uso dessa capacidade. Essa é a base da ética ambiental.

Para os seres humanos, o ambiente social tem o mesmo peso que o ambiente natural e ambos concorrem para formar o ambiente humano. A estabilidade desse ambiente depende de um sadio equilíbrio 
entre as condições sociais e naturais. Um desajuste entre sociedade e natureza origina uma crise ambiental. Os ecossistemas humanos (aldeia, vila ou cidade) nascem, amadurecem e entram em decadência como os ecossistemas naturais, segundo as relações entre o ambiente natural, a realidade biológica da população e as expressões sociais, políticas, econômicas e religiosas do grupo. A crise ecológica aponta para a decadência do atual paradigma de intervenção no meio ambiente e de convivência entre os seres humanos e destes com a natureza.

A situação de fome, pobreza e injustiça de multidões de seres humanos é a face social da crise ecológica. O mesmo sistema que degrada a natureza, reduzindo-a a mercadoria, avilta a existência de seres humanos, sujeitos a uma luta diária pela sobrevivência, porque não participam do mercado. As feridas infligidas ao meio ambiente são mais trágicas e devastadoras, quando acompanhadas de chagas sociais que empurram grandes maiorias populacionais de países pobres a uma procura desesperada para satisfazer as necessidades básicas. Nessa crise civilizacional o grito desesperado da natureza se levanta em uníssono com o grito angustiado de milhões de seres humanos por respeito pelos mecanismos de reprodução da vida e pelos diversos fatores naturais e sociais que a possibilitam. A crise ambiental não tem solução sem uma convivência social justa e um acesso igualitário aos bens necessários à sobrevivência.

O paradigma ecológico surgiu para fazer frente a essa crise. Não bastam soluções cosméticas, impõe-se uma mutação na percepção da realidade, especialmente na relação com a natureza e na construção do entorno social. Isto exige o surgimento de uma nova compreensão do próprio ser humano, um modo diferente de construir o discurso ético e uma visão renovada da natureza como criação de Deus. O debate entre antropocentristas e biocentristas insere-se nesse contexto e implica questões de antropologia, de ética e de teologia da criação. Sem a explicitação dessas questões, permanece o impasse e não se chega a um discurso ético consistente.

O paradigma ecológico veio para superar o paradigma moderno da autonomia humana solipsista, da aventura de conquista e domínio da natureza pela ciência e a técnica, do uso desmedido e do desfrute imprudente dos recursos naturais, da passagem do regime da natureza para o regime da sociedade, da ética procedimental e utilitarista.

\section{Questões antropológicas}

Nas críticas que posições antropocêntricas e antiantropocêntricas levantam uma contra a outra, está subjacente uma certa concepção de ser humano. O ponto de partida da argumentação e o objetivo da 
crítica é antropológico. As duas tendências confrontam-se criticamente com a visão moderna do ser humano. O ponto de referência é o ser humano autônomo e empreendedor, vencedor das determinações e auto-suficiente, dominador da natureza caótica e conquistador do mundo. O contexto cultural do debate crítico é a modernidade.

Nas posições antropocêntricas existe uma maior aceitação dos pressupostos antropológicos da modernidade, apesar da crítica ao modo como o ser humano se relaciona com o meio ambiente. $\mathrm{O}$ ponto de referência é sempre o ser humano e um ser humano autônomo e isolado em relação ao conjunto de interdependências do meio em que vive. Não existe uma compreensão a partir da sua inter-relacionalidade e intersubjetividade. O ponto de referência são os interesses humanos, sejam eles materiais ou espirituais, não se importando pelos possíveis interesses do ambiente e da comunidade biótica que o rodeia. Nesse sentido não assume o paradigma ecológico, porque não capta o ser humano inserido numa rede de interdependências e conexões vitais que formam o ecossistema humano e natural. Nisso consiste justamente a fragilidade da posição antropocêntrica moderna. Uma antropologia adequada ao paradigma ecológico precisa superar a concepção solipsista e centrada puramente nos interesses humanos para chegar a uma compreensão ecosistêmica do ser humano.

Nas posições biocêntricas existem duas tendências: uma atomizadora dos seres vivos entendidos como sujeitos de bem estar ou centros teleológicos de vida e a outra ecocêntrica centralizada nas comunidades bióticas. As duas são críticas da referência humana no equacionamento dos problemas ecológicos. A primeira aplica, no fundo, a concepção moderna de ser humano aos seres vivos, porque os atomiza em sujeitos autônomos e detentores de direitos. Os animais são incluídos na comunidade humana moderna. Os autores da Animal Liberation são a máxima expressão dessa tendência. Não se supera a visão moderna, como quer o paradigma ecológico, mas unicamente se amplia essa compreensão para incluir também os sujeitos de vida ou de bem estar. Assim, existe um antropomorfismo e atomismo dos seres vivos para aplicar a eles aquilo que a modernidade pensou do ser humano. Por isso, se fala, por exemplo, dos direitos dos animais. Essa tendência peca de antropomorfismo ao querer aplicar aos animais o conceito moderno de direitos e de falta de sensibilidade ecológica ao compreender os seres vivos como indivíduos e sujeitos, desconhecendo as interdependências ecosistêmicas.

A única tendência que assume integralmente o paradigma ecológico é o biocentrismo global, porque tem como ponto de referência não os indivíduos mas a comunidade biótica. Trata-se da posição verdadeiramente contrária ao antropocentrismo moderno. Compreende o 
ser humano como um elo a mais no encadeamento vital dos ecossistemas. Ele não detém um papel primordial na comunidade biótica. Depende dos mesmos processos vitais como qualquer outro ser vivo. A fragilidade dessa tendência é a redução biológica do ser humano e o esquecimento de que o ser humano, diferente dos outros seres vivos, tem um confronto cultural com seu meio ambiente. Ele constrói um entorno humano, ao lado e em relação com o ambiente natural. Esse entorno cultural é uma necessidade do ser humano e não necessariamente está em dissonância com o ecossistema natural. Durante milênios a humanidade soube conjugar harmonicamente entorno social e ambiente natural. As revoluções científicas e tecnológicas modernas introduziram o conflito entre o ser humano e a natureza. Portanto, o problema não está no ser humano em si mesmo, mas numa certa concepção introduzida pela modernidade.

O ecocentrismo assume uma posição antiantropocêntrica, porque se contrapõe às pretensões de um ser humano solipsista em sua autonomia e "Prometeu" em seu confronto com a natureza. Esse ser humano auto-suficiente e onipotente produzido pela modernidade, descontextuado de inter-relações com seu entorno humano e das interdependências vitais do seu ambiente natural é o responsável pelo desastre ecológico que assistimos. O desafio é superar essa concepção antropológica e não simplesmente negar a posição privilegiada do ser humano na escala da natureza. Por ter consciência e intencionalidade éticas, ele assume um papel fundamental no contexto da biosfera. Sem centrar-se naquilo que o ser humano pode e deve fazer para preservar o ambiente natural, não existe ética ecológica. Eludir o ser humano na questão ecológica é alijar o elo central da questão e não dar uma verdadeira solução ao problema. Portanto, não se pode fugir do "princípio antropotópico"17, porque o equacionamento de desafio ambiental depende de uma mudança de atitude do ser humano. Não se trata de negar o papel do ser humano, mas de chegar a uma concepção antropológica condizente com o paradigma ecológico.

Trata-se de superar a mentalidade moderna que vê o ser humano como independente e desconectado do seu ambiente vital, posicionado acima e diante da natureza reduzida a objeto, para compreendê-lo inserido numa rede de interdependências bióticas e sociais das quais depende a sua sobrevivência e crescimento vital, humano e espiritual. $\mathrm{O}$ ser humano precisa entender a natureza como útero no qual foi gerado e nutriz que o alimenta e faz crescer. A natureza deve ser respeitada e preservada simplesmente porque é a matriz da vida da qual o ser humano é o elo mais desenvolvido. Nesse sentido, a natu-

17 A palavra "antropotópico" é composta de ánthropos (ser humano) e tópos (lugar) para apontar para o lugar central do ser humano em qualquer discurso ético. 
reza não pode ser reduzida a servir apenas os interesses humano, porque a vida é um bem maior no qual o ser humano está inserido.

Para chegar a essa visão, o ser humano precisa aceitar que a natureza tem o seu fim como matriz da vida e esse fim deve ser respeitado. Ela tem interesse no equilibrio dos fatores que possibilitam a reprodução da vida. O ser humano não pode transformá-la em puro meio de satisfação de seus interesses. É necessário superar o modelo de competição e introduzir o modelo de cooperação entre a humanidade e a natureza para que seja possível uma harmonização dos interesses de ambas. Tradicionalmente se afirma que o ser humano necessita da comunidade humana para viver. A crise ecológica leva a superar essa redução humana e a dar-se conta de que se depende de outras instâncias identificadas com a natureza. Respeitar seus interesses e exigências traz conseqüências para os humanos. Assim a responsabilidade humana é alargada pela tese de que os seres viventes também merecem consideração moral e são objetos imediatos de moralidade. Tratase de que o ser humano aceita e assuma o fim da natureza como algo próprio e a considere como partner.

O ser humano precisa convencer-se de que foram necessários milhões de anos de evolução biológica dos seres vivos para que muito recentemente, na história da vida, ele surgisse. Se compararmos essa história com a escala de um ano, o ser humano surgiu nos últimos minutos. O conhecimento desse dado deve levar a uma atitude de maior humildade diante da natureza e admiração pela matriz comum da vida. A dinâmica dominadora e transformadora dos recursos naturais, possibilitada pela ciência e técnica modernas, deu origem à atitude autônoma e orgulhosa diante da natureza, responsável última pela atual crise ecológica. Impõe-se recuperar a consciência da indigência do ser humano e da vulnerabilidade das condições e possibilidades dos dinamismos vitais e uma correspondente atitude de humildade e respeito diante da vida.

A ecologia demonstrou que o equilíbrio dos ecossistemas naturais é frágil e vulnerável. Por isso, a intervenção do ser humano no meio ambiente deve ser cuidadoso e respeitador dos processos bióticos. Essa vulnerabilidade não se suspeitava antes do aparecimento dos danos causados. Ela manifesta, através dos efeitos, que o modo de agir humano mudou radicalmente em relação ao passado, sendo-lhe acrescentado um novo objeto totalmente novo, a biosfera do planeta terra, pela qual o ser humano terá que responder já que tem poder sobre ela. A natureza é hoje mais vulnerável que antes, porque está mais exposta à manipulação tecnológica. A violação das leis naturais e dos dinamismos vitais supõe mudanças estruturais no entorno ambiental do ser humano e repercute inevitavelmente na sua vida e na realização da 
sua liberdade. Se ele é um ser-no-mundo, integrado na realidade global que o rodeia, a deterioração do entorno natural afeta gravemente a sua estrutura pessoal. A vulnerabilidade da natureza aponta para a vulnerabilidade do próprio ser humano. Se a sua matriz vital está sendo destruída, é o próprio ser humano que se deteriora.

O antropocentrismo moderno suscita um ser humano "prometeico", sempre mais auto-suficiente na satisfação das suas necessidades e confiante em suas próprias capacidades. Passa uma auto-imagem de força e vitória sobre os condicionamentos. Esquece que é um ser indigente e vulnerável como todo ser vivo. É necessário recuperar essa dimensão de vulnerabilidade do ser humano se queremos chegar a uma antropologia condizente com o paradigma ecológico.

A pessoa humana é uma estrutura indigente, isto é, frágil e quebradiça, não só na sua gênesis, mas também no seu desenvolvimento vital e o é desde muitas perspectivas. Todas as realidades relacionais e interdependentes, como os seres vivos, as comunidades bióticas, a sociedade humana, o mundo afetivo, são, nesse sentido, indigentes, pois carecem de auto-suficiência.

Os clássicos gregos e romanos definiram o ser humano como o animal mais desnudo. Plínio o expressa de uma maneira clara na sua fábula do homem: "No dia de seu nascimento, só o ser humano é lançado desnudo para fora sob o solo inclemente, começando imediatamente a chorar e gemer. Nenhum outro animal é mais propenso às lágrimas, já desde o primeiro momento de sua vida. Mesmo o tão comentado sorriso do bebê só aparece depois de seis semanas. Este modo débil de vir à luz é seguido por um tempo de cativeiro de que não padecem os filhotes de outros animais, pois a criança, mesmo nascendo de um modo bem sucedido, permanece em total dependência, amarrado de mãos e pés, e chorando"18.

Na modernidade aparece a mesma idéia em Rousseau: "Nascemos fracos, precisamos de força; nascemos desprovidos de tudo, temos necessidade de assistência; nascemos estúpidos, precisamos de juízo. Tudo o que não temos ao nascer, $e$ de que precisamos como adultos, nos é dado pela educaçẫo"19. A necessidade de educação está baseada na própria indigência humana. Os animais não necessitam de educação, porque estão programados pelo instinto. Dito de outro modo o ser humano não se reconhece em suas faculdades e prerrogativas, mas em sua fragilidade e em suas necessidades. Ecce Homo diz Rousseau.

17 PLINE, L'ANCIENT, Histoire Naturelle, Paris: Les Belles Lettres, 1950, VII, 2-5.

${ }^{19}$ J. J. ROUSSEAU, Emile ou de l'Éducation, Paris: Garnier, 1961, p. 7. 
O ser humano "prometeico" moderno pensou que tinha superado essa indigência, mas descobre que é essencialmente carente, necessitado de outros e do ambiente natural e social para viver. A sobrevivência do ser humano está pendente da satisfação de uma série de necessidades. Não pode pensar-se auto-suficiente, porque depende de uma rede de inter-relações que o sustentam. Essa carência o torna vulnerável aos desequilíbrios vitais e humanos. A vulnerabilidade humana é diretamente proporcional à vulnerabilidade do próprio ambiente natural e social em que vive.

A vulnerabilidade revela-se nas diferentes dimensões do ser humano: corpo, psique e espírito. A experiência corporal é a primeira e mais fundamental consciência da fragilidade e indigência humanas. $O$ corpo manifesta cansaço, doença, dor; resiste aos propósitos e desejos interiores; revela na aparência somática os efeitos erosivos do desgaste do tempo; lembra continuamente a possibilidade da morte. Pela corporeidade o ser humano insere-se no seu entorno e participa da rede de interdependências do seu ambiente, tornando-se um ser-nomundo. Como polo de inserção na realidade e dimensão essencial da totalidade pessoal, a experiência corporal impede que o ser humano se sinta independente do seu meio ambiente. Ele não pode encontrar-se diante ou fora da natureza que o rodeia e da qual depende. O corpo é o cordão umbilical que o liga essencialmente com seu entorno natural e social. Como não pode viver sem corpo, também não pode sobreviver fora da sua comunidade biótica e humana. O corpo é a base das inter-relações que constituem a pessoa.

Hoje a revolução biotecnológica tenta vencer a vulnerabilidade corporal. A ciência poderá libertar o ser humano do flagelo de muitas doenças, mas não poderá obsequiar-lhe a imortalidade somática. $O$ corpo biológico caminha inexoravelmente para a morte por mais que se queira e possa postergá-la. A morte é uma lei sábia da natureza para que a vida possa ser reproduzida, tentar negá-la provocará desequilibrios e distúrbios bióticos. Atualmente a indigência corporal é menos experimentada do que em tempos passados, em que pestes e catástrofes ceifavam milhares de vidas, porque existem recursos para vencer muitos perigos que ameaçam a vida corporal.

Se em nossos dias a fragilidade somática é menos visível, porque as ciências da saúde prometem a cura, a vulnerabilidade psíquica é a própria expressão hodierna da indigência humana. As terapias psicológicas multiplicam-se e tornam-se uma necessidade. A interioridade é atravessada por desejos desencontrados e por fantasmas ameaçadores que provém principalmente do subconsciente, fruto de experiências traumáticas de infância em que a criança não experimentou amor e aceitação, provocando insegurança afetiva e falta de rumo existenci- 
al. A desestruturação social, a violência urbana, o desemprego e a falta de perspectivas de futuro, a ruptura da convivência familiar agravam ainda mais a insegurança interior com angústia e medo.

A mentalidade cultural que alimenta a interioridade das pessoas é inspirado pelo narcisismo instigador de desejos e simulacros de sentido para a vida que esvaziam e provocam desorientação e tédio. Como solução, buscam-se substitutivos na droga, nos sons ensurdecedores, na vida frenética, nas experiências limite. Tem-se medo do silêncio, porque ele revela a confusão interior. Vive-se um profundo vazio existencial porque os apelos se sucedem sem oferecer um critério de avaliação e um rumo para a vida. Existe uma exasperação apelativa dos desejos sem oferecer um sentido que ajude a canalizar e orientar, ao contrário, apresenta-se um desfile de simulacros de sentido que justamente desorientam. Os jovens são as principais vítimas dessa situação e sinais demonstrativos da atual fragilidade psíquica.

Se a vulnerabilidade psíquica é a própria expressão atual da indigência humana, ela se explica por uma fragilidade mais profunda que é espiritual. O materialismo e o relativismo imperantes impedem encontrar um sentido existencial que plenifique a abertura transcendental do ser humano. Não existe o absoluto, tudo é relativo e imanente. Não existe a verdade e o bem como critérios universais e expressões do sentido para o conhecer e o agir. Vive-se a insignificância da vida e o imediatismo do presente. Não tem sentido colocar a questão do sentido. O que importa é a fugacidade do presente, sem se preocupar com o futuro. A pessoa não se coloca questões fundamentais, não se pergunta pelo sentido da sua vida. Vive um nada interior. Por isso, o niilismo é a própria personificação cultural da atual indigência espiritual do ser humano.

A modernidade que pretendeu tirar o ser humano da minoridade, dando-lhe autonomia, força e recursos para vencer os determinismos, revelou, ao contrário, a vulnerabilidade interior do ser humano. Em vez da maioridade autoconfiante e auto-suficiente, manifestou a profunda fragilidade humana. A acentuação das capacidades humanas de auto-superação e o conseqüente esquecimento da vulnerabilidade expôs a ferida da indigência. Por isso, é importante recuperar para a antropologia a dimensão da vulnerabilidade.

O pobre, o abandonado, o necessitado são a própria expressão dessa constante humana. Eles recordam a todo ser humano sua fragilidade. A modernidade, ao querer superar a vulnerabilidade pela ciência e a técnica, renega e alija aqueles que a manifestam. A indigência social é culpabilizada como falta de autonomia e empenho pessoal. Todo aquele que se revela frágil e vulnerável não tem lugar na sociedade moderna. 
Ela representa o conjunto daqueles que são vitoriosos e dotados de capacidades para vencer. A vulnerabilidade não pode fazer parte daquele que atingiu a maioridade. A fragilidade é uma característica do menor e do incapacitado. Mas, por uma ironia da história, a modernidade justamente tornou o ser humano mais vulnerável.

A sobrevivência natural e cultural dos seres humanos depende do equilibrio das condições bióticas e sociais do seu entorno. As expressões atuais da indigência humana apontam para uma crise ambiental. A destruição e desestruturação do entorno manifestam-se na interioridade destroçada da geração atual A consciência da própria fragilidade ajuda a levar em consideração a vulnerabilidade do ambiente natural nas decisões de intervenção e a desenvolver atitudes de preservação e cuidado em relação a ele.

A modernidade acentuou no ser humano o modo de ser do trabalho que transforma a natureza. Trata-se de assumir uma atitude ativa $\mathrm{e}$ interventora diante da realidade. $\mathrm{O}$ acento no trabalho, fez esquecer e relegar a segundo plano o modo de ser do cuidado ${ }^{20}$. São dois modos básicos de ser-no-mundo. Pelo trabalho o ser humano entra em confronto cultural com a natureza, tentando moldar o ambiente às condições humanas. Constrói o seu habitat e adapta o meio aos seus propósitos. Prolonga a evolução, introduzindo realidades novas que a própria natureza não teria produzido. Pelo trabalho, o ser humano pilota a evolução, fazendo interagir natureza e sociedade num processo de simbiose. Esse processo iniciou no neolítico e entrou em aceleração na revolução tecnológica moderna. O modo de produção capitalista motivou essa aceleração, levando a uma corrida frenética em busca de recursos naturais a transformar em mercadoria e originando patologias no modo de ser do trabalho. As patologias provém da mercantilização da natureza e da transformação da própria força de trabalho em mercadoria. Assim o meio ambiente natural e o ser humano foram sendo degradados, manipulados e reduzidos a objetos a serviço de interesses lucrativos. Faltou desenvolver o modo de ser do cuidado que corrige os excessos da intervenção do trabalho. Cuidado e trabalho precisam andar juntos. A atual situação de degradação natural e social é fruto dessa dissociação.

Diante da crise ecológica e civilizacional, torna-se urgente recuperar e desenvolver mais nas pessoas o modo de ser do cuidado, esquecido pela predominância do trabalho e pelo acento na autonomia $\mathrm{e}$ independência. Para mostrar que o cuidado é uma constante antropológica do ser humano e não apenas uma característica cultural ou

\footnotetext{
${ }^{20}$ L. BOFF, Saber cuidar: Ética do humano - compaixão pela terra, Petrópolis: Vozes, 1999, pp. 92-103.
} 
pessoal, nada melhor do que recorrer à mitologia que expressa profundas estruturas humanas através de uma linguagem simbólica. Heidegger em sua obra Ser e Tempo, traz a fábula de um autor romano chamado Higino que fala de cuidado como alguém que configurou o ser humano nos seus inícios ${ }^{21}$ :

"Certa vez, atravessando um rio, 'Cuidado' viu um pedaço de terra argilosa: reflexivo, tomou um pedaço e começou a lhe dar forma. Enquanto refletia sobre o que criara, interveio Júpiter. 'Cuidado' pediu-lhe que desse espírito à forma da argila, o que ele fez de bom grado. Como 'Cuidado' quisesse dar o seu nome ao que tinha dado forma, Júpiter o proibiu e exigiu que fosse dado o seu nome. Enquanto 'Cuidado' e Júpiter disputavam sobre o nome, surgiu também a Terra, querendo dar o seu nome, uma vez que tinha fornecido um pedaço de seu corpo. Os contendentes tomaram Saturno como árbitro. Saturno pronunciou a seguinte decisão aparentemente eqüitativa: 'Tu, Júpiter, por teres dado o espírito, deves receber de volta na morte o espírito e tu, Terra, por teres dado o corpo, deves receber o corpo. Como, porém, foi 'Cuidado' quem primeiro o formou, ele deve pertencer a 'Cuidado' enquanto viver. Como, no entanto, sobre o nome há disputa, deve ser chamado 'homo', pois foi feito de húmus (terra)".

Na fábula aparece o aspecto da fragilidade, no fato de o ser humano ter sido formado da argila da terra. A indigência do corpo aponta para esse aspecto. A fragilidade do homem o marca de tal forma que seu próprio nome expressa essa dimensão. Ele é designado como homo, que provém de humus. Por isso, enquanto estiver vivo pertencerá a "Cuidado", porque necessita de desvelo e solicitude. O cuidado pertence à presença humana no mundo. Essa presença acontece no tempo. Por isso, Saturno, o deus do tempo, intervém para dirimir a disputa entre Júpiter, "Cuidado" e a Terra em relação ao ser humano. Define os papéis e a essência humana. "Cuidado" rege o seu percurso temporal. Ser lançado nesse percurso torna o ser humano frágil e necessitado de cuidado.

Apesar de o ser humano tentar superar sua indigência, satisfazendo suas necessidades pelo trabalho, sua necessidade fundamental é receber cuidado, porque a vida que o anima é frágil, não auto-suficiente, já que feita de diversas interdependências que sustentam seu dinamismo vital no tempo. Por ser um vivente e enquanto vive, pre-

${ }^{21}$ A fábula está reproduzida no original latino com a respectiva tradução em $\mathrm{M}$. HEIDEGGER, Ser e Tempo, Parte I (tradução de Márcia de Sá Cavalcanti) Petrópolis: Vozes, 1988, 2a Edição, pp. 263-264. Para a tradução da palavra latina cura é preferível "cuidado" e não "cura" como aparece no texto em português. 
cisa de cuidado e dedicação. $O$ pobre e o abandonado experimentam diariamente essa realidade. Necessitam de cuidado e de ajuda constantes para sobreviver. A presença deles recorda e motiva atitudes de cuidado.

A consciência da fragilidade da sua própria vida, exigindo desvelo, leva o ser humano a dar-se conta que a vida, pulsando no seu entorno natural e animando as interrelações vitais da sua comunidade biótica é também frágil, necessitada de solicitude e cuidado. As intervenções humanas no ambiente através do modo de ser do trabalho precisam ser acompanhadas pelas preocupações com a fragilidade do equilíbrio vital dos ecossistemas. Numa época de crise ecológica o cuidado com a reprodução da vida deve ter a primazia sobre o trabalho de transformar a natureza e responder aos interesses humanos. Isto já introduz a questão ética.

\section{Questões éticas}

$\mathrm{Na}$ discussão entre posições antropocêntricas e biocêntricas esłá implicada além de uma visão de ser humano, também maneiras de conceber a ética. Alguns defendem uma ética normativa deontológica para a ecologia. São os que privilegiam a salvaguarda dos interesses materiais dos pósteros e a necessidade de impor limites no acesso aos recursos e no aumento da população. Daí a necessidade de criar normas consensuadas para preservar os recursos, válidas para todos. Outros advogam uma ética utilitarista que parte da capac:dade de ter sensações de prazer e dor, tentando sopesar danos e benefícios de uma ação. Entre esses estão, principalmente, os defensores da Animal Liberation. Um terceiro grupo é mais radical, patrocinando uma ecologia mais profunda. São os partidários da Deep Ecology e do biocentrismo ecocentrico. Defendem um cambio radical do ser humano, uma mudança da Gestalt, da maneira de se relacionar com a natureza, assumindo uma posição biocentrada. Trata-se da necessidade de uma mudança de modelo. A ética precisa inspirar-se no paradigma ecológico se quiser construir um discurso pertinente para a crise ambiental e propor soluções adequadas e eficazes para a ação humana frente à natureza.

Se o paradigma ecológico surgiu como uma crítica radical ao solipsismo e individualismo do paradigma moderno, então as éticas inspiradas nesse modelo não são adequadas. Éticas que privilegiam a autonomia de sujeitos isolados ou partem de puras normas criadas à base do consenso não servem para pensar realidades interdependentes $\mathrm{e}$ inter-relacionadas como são as comunidades bióticas. Éticas procedimentais e utilitaristas que imperam na mentalidade atual não são adequadas para solucionar a crise ecológica, porque não assumem 
o ponto de vista central da ecologia: as interdependências de um ecossistema vital. Ou privilegiam os indivíduos, defendendo os direitos de cada um; ou reduzem-se às inter-relações humanas. A pergunta é como construir uma ética verdadeiramente ecológica. Não se pode simplesmente aplicar o modelo moderno de ética antropocêntrica para pensar as questões ecológicas como fazem várias tendências. Nesse sentido, as ecologias profundas e bioecocentradas são mais coerentes em assumir o novo paradigma.

Tratando-se de ética não se pode fugir do "princípio antropotópico", isto é, da alusão humana da ética, já que ela sempre se refere ao agir enquanto humano. Não existe ética sem intencionalidade humana. Nesse sentido não existe ética que não seja "antropocêntrica". Só os humanos levantam questões éticas e constróem discursos éticos. Portanto, a ética ecológica não pode eludir a sua referência humana. Por outro lado, é preciso superar um tipo de antropocentrismo "prometeico" introduzido pela modernidade, responsável pela crise ecológica e partir de uma concepção de ser humano apropriada à ética ecológica, como foi demonstrado mais acima.

A ecologia profunda insiste na necessidade de uma mudança gestáltica do ser humano e a superação de uma ética construída em moldes normativos. Em outras palavras, essa mudança exige uma ética de atitudes ou do caráter ou da virtude. Trata-se de uma ética que provoque uma transformação radical e uma conseqüente modificação das atitudes diante do meio ambiente. É o que no mundo antigo e medieval se chamava ética da virtude. Hoje existe uma recuperação dessa categoria ética e uma renovada insistência na sua importância para a educação ${ }^{22}$. A ética não terá incidência na realidade se ela não chegar a modelar a personalidade dos agentes e levar a interiorizar atitudes que se expressem num ethos cultural do grupo.

Só uma personalidade moral, configurada em atitudes de sensibilidade ecológica e reforçada por uma cultura ética correspondente, tem força para fazer frente a uma cultura do consumismo, do desperdício, da indiferença diante da natureza. Normas, por mais que sejam fruto de consenso, não conseguem motivar, se não estão sustentadas por atitudes interiores veiculadas por um ethos cultural. Nesse sentido, uma verdadeira ética ecológica só é possível nos moldes de uma ética da virtude. O paradigma ecológico exige, em sua ética, muito mais do que puras normas convencionadas de proteção da nature$z a$, requer uma forte personalidade moral com sensibilidade

22 A. COMTE-SPONVILLE, Pequeno Tratado das Grandes Virtudes, São Paulo: Martins Fontes, 1995. 
meioambiental e um apropriado clima cultural ecológico que sustente essa sensibilidade.

A posição biocêntrica significa uma mudança de visão. Uma ética não se completa, fundamentada apenas normas. Deve também querer mediar um ethos, um enfoque afetivo que motive a agir de acordo com o que é eticamente correto. Em outras palavras, pretende criar atitudes e formar a personalidade moral em relação ao meio ambiente. Nesse sentido não basta uma visão estética da natureza. Ela dependerá do gosto dos sujeitos. O interesse estético é mutável. A visão biocêntrica advoga a passagem de um valor puramente estético para um valor ontológico da natureza que fundamente a relação com ela.

Um dos impasses da ética ecológica é querer aplicar o discurso da ética da justiça para resolver os problemas ambientais. A preocupação com a justiça surgiu para equacionar questões relativas às inter-relações humanas e não se pode aplicar simplesmente suas categorias e critérios para as interdependências das comunidades bióticas. Nesse sentido, é problemático falar de contrato natural como propõe $\mathrm{M}$. Serres ${ }^{23}$ ou de direitos dos animais como quer P. Singer ${ }^{24}$, porque existe uma antropomorfização da natureza e dos animais nos moldes da modernidade. É necessário encontrar outro modelo que tenha como ponto de partida a dinâmica dos ecossistemas naturais e não tentar compreender as inter-relações naturais segundo critérios criados para pautar a convivência humana. Por isso, fala-se sempre mais de uma "ética do cuidado" que vem completar a "ética da justiça" que não consegue equacionar eticamente certas realidades humanas e, principalmente, dinamismos meioambientais nos quais está implicada a vida.

Uma ética que queira ter como conteúdo central a preservação e reprodução da vida, terá que assumir o modelo do cuidado. Uma posição biocêntrica não condiz com o puro esquema da justiça, porque este exige sujeitos independentes que podem reivindicar seus direitos por si ou por procuração de outros. Diante da exigência de direitos existe sempre a obrigação de deveres. Ora esse esquema não é aplicável a realidades totalmente interdependentes cujos dinamismos vitais dependem essencialmente de relações, não de centros independentes de vida.

\footnotetext{
${ }^{23}$ M. SERRES, Le Contrat Naturel, Paris: François Bourin, 1990. Crítica A essa posição: P. GARDEIL, "Considerations sur l'auteur de la nature. A propos de Michel Serres", Études $376 / \mathrm{n}^{\circ} 2$ (1992) 231-238.

${ }^{24}$ P. SINGER, Animal Liberation, New York, 1990, $2^{\text {a }}$ ed. Crítica A essa posição: P. CARRUTHERS, The animals issue: moral theory in practice, Cambridge: Cambridge University Press, 1992.
} 
A vida em seu sentido mais amplo é energia vital que intercorre nos seres que formam determinada comunidade biótica. Ela depende de inter-relações que sustentam o elã vital. Nesse sentido, a vida nunca é auto-suficiente, porque nenhum ser vivo basta-se a si mesmo. Ele depende de diversos fatores abióticos e bióticos que configuram seu ecossistema. Por não ser auto-suficiente, a vida é uma realidade frágil que necessita de certas condições para se reproduzir. Por isso, é preciso ter cuidado com o entorno que possibilita o milagre da vida. A fragilidade e indigência da vida exigem do ser humano o modo de ser do cuidado na sua relação com o meio ambiente.

A ética, correspondente ao modo de ser do cuidado, não pode ser uma ética de princípios e normas que defendem direitos, mas uma ética da virtude que suscita atitudes e forma o caráter dos agentes humanos. Modos de agir que se sustentem sobre uma conscientização ecológica cultural e sobre uma transformação da sensibilidade pela vida. As exigências do cuidado não podem ser reduzidas a normas $\mathrm{e}$ responder a direitos, dependem de atitudes interiorizadas e de contextos culturais que valorizam a vida. O cuidado não é normatizável em regras de conduta. Ele se expressa em valores e atitudes para os quais é necessário educar-se. Por isso, seria urgente apontar as virtudes condizentes com o cuidado da vida e o respeito às comunidades bióticas.

Isto não significa que normas de proteção e preservação do meio ambiente não sejam necessárias. Elas devem configurar o direito ambiental que impõe limites e reprime abusos contra a natureza, mas não consegue motivar a sensibilidade e orientar os comportamentos que é uma questão ética. A crise ecológica necessita antes de mais nada de ética, porque se trata de uma mudança paradigmática no modo de encarar a natureza. A pura resposta jurídica não resolverá os problemas ambientais.

A ética ambiental inspirada pelo modelo do cuidado estará atenta às leis naturais do equilíbrio vital de um ecossistema descobertas pela ciência da ecologia. A consciência da fragilidade da vida e a correspondente atitude de cuidado leva a respeitar as leis que regem as interdependências bióticas que possibilitam a reprodução da vida. Por isso, deve existir um contínuo intercâmbio entre a ética ambiental e o saber ecológico.

Diante das considerações feitas, pode-se dizer que a ética ecológica é formalmente referida ao agente humano e, nesse sentido, é sempre antropotópica, mas materialmente ela tem como conteúdo a vida e, portanto, é biocentrada. Por ser ética ela só pode ser atribuída a sujeitos humanos, porque só eles podem desenvolver ações intencionadas, 
mas enquanto ecológica está referida ao dinamismo vital que intercorre numa comunidade biótica. Portanto, as duas categorias básicas da ética ecológica são a atitude humana de cuidado diante da fragilidade da vida e o dinamismo vital que mana entre os seres vivos interdependentes de uma comunidade biótica.

\section{Questões teológicas}

As questões antropológicas e éticas implicadas na discussão ecológica levantam críticas à tradicional teologia da criação ${ }^{25}$, principalmente no que se refere ao "dominai a terra" e "submetei os animais" em Gn 1, 28. A interpretação tradicional dada ao papel do ser humano na criação, geralmente, serviu de justificativa para um domínio explorador dos recursos naturais. Mas, quando se tenta seguir a mentalidade hebraica que inspira esses versículos, chega-se a outra conclusão.

Antes de mais nada é necessário deixar claro que o contexto bíblico da criação é teocêntrico e não antropocêntrico. O relato criacional não está centrado no ser humano, mas na ação criadora de Deus. Nesse sentido, o texto bíblico não termina no surgimento do ser humano como sempre se pensa, mas no descanso sabático de Deus. O repouso de Deus é a volta a si, depois de ter saído de si para criar. Deus se auto-limitou ao sair de si e criar algo diferente de si. Abriu um espaço onde fosse possível o aparecimento das criaturas. Mas esse espaço está em Deus e, por isso, ao descansar e voltar a si, Deus traz consigo todas as criaturas. Nesse sentido, elas também descansam em Deus. Não só Deus descansa das criaturas, porque volta a si, mas elas repousam diante do olhar pacificador de Deus, porque encontram proteção diante da fragilidade de sua vida que as pode novamente reduzir a nada.

A compreensão do descanso sabático de Deus foi reduzido a fundamento de prescrições religiosas, perdendo seu significado para a compreensão da criação. As criaturas, na sua fragilidade, encontram em Deus o seu repouso diante da contínua ameaça de aniquilação. Por isso, elas descansam em Deus que as mantém em vida. O ser humano é também uma ameaça para elas. O descanso sabático recorda continuamente que os seres vivos são criaturas de Deus e não simples objetos de manipulação a serviço de interesses humanos. A rotina do trabalho de intervenção na natureza é interrompida pelo dia do sábado ou pelo ano sabático, para lembrar o ser humano que a natureza é

\footnotetext{
${ }^{25}$ Para uma compreensão ecológica da criação ver: J. MOLTMANN, Deus na crinçăo. Doutrina ccológica da criação, Petrópolis: Vozes, 1993; J. R. JUNGES, Ecologia e cria§ão. Resposta cristã à crise ambiental = Coleção CES, 7, S. Paulo: Loyola, 2001.
} 
criação de Deus. A natureza é deixada descansar, o ser humano não intervém pelo seu trabalho para que ela recupere seu ritmo e repouse em sua harmonia. $O$ afã de lucro do capitalismo significou uma gradativa anulação dos dias de descanso, reduzindo a natureza à mercadoria, negando sua condição de criação de Deus e, principalmente, não a deixando em repouso ao quebrar continuamente o seu equilibrio.

Outro aspecto da doutrina bíblica da criação com incidência na questão ecológica é a afirmação de que o ser humano foi criado à imagem e semelhança divina. Essa afirmação sempre foi usada para defender a precedência e o protagonismo do ser humano no conspecto da criação. Sem dúvida é afirmada a posição privilegiada na escala dos outros seres vivos. A questão é o significado desse lugar especial. Em que o ser humano é feito à imagem e semelhança divina? Certamente não no senhorio absoluto de Deus. Ele não é senhor, mas um puro administrador da criação que lhe é entregue por Deus em cuidado. Deus criou o ser humano como seu interlocutor entre as criaturas. Por isso, foi criado à imagem do Filho para que espelhasse o rosto do Filho, sendo assim o representante de Deus diante da Criação e o representante das criaturas diante de Deus. A imagem divina do ser humano está ao serviço dessa representação. O conteúdo da sua semelhança com o Filho é o papel de mediador entre Deus e as criaturas. Trata-se de uma representação subsidiária de Deus na linha da criação e do descanso das criaturas em Deus. O papel do ser humano não é apropriar-se da natureza como dono e explorador, mas realizar a função de um jardineiro que cuida da harmonia e beleza do jardim criado por Deus. Portanto, a representação deve ser exercida na perspectiva do cuidado.

A compreensão do significado, para a criação, do descanso sabático de Deus e da representação subsidiária do ser humano leva a interpretar de outro modo o que foi tradicionalmente traduzido em Gn 1, 28 por "dominai a terra" e "submetei dos animais". Não se trata de dominar e submeter no sentido e subjugar e oprimir, porque isto seria a negação do senhorio de Deus. Em relação à terra, o ser humano é convidado a ocupá-la para seu sustento. A terra está a serviço da reprodução da vida e a sua ocupação é para tirar dela o alimento.

Em relação aos animais, o ser humano é convidado a ser um juiz de paz na linha de Is $11,6-9$. Esse texto apregoa a harmonia vegetariana entre os animais, já que no relato da criação só a erva é dada como alimento a todo ser vivo (cf. Gn 1, 29-30). A licença para comer carne só virá depois do pecado e do dilúvio, embora fique a proibição de consumir carne com vida, isto é, com seu sangue (Gn 9, 3-4). O fato 
do ser humano dar nome aos animais (Gn 2, 19c-20) tem o sentido de introduzi-los na comunidade lingüística humana, considerando-os como parceiros de ajuda (Cf. Gn 2,18) e de sorte (Cf. Ecl 3, 19). Portanto, não se trata de submissão, mas de parceria.

\section{Teses para uma Ética ecológica}

1. Para a compreensão comum e tradicional, a ética diz respeito apenas a realidades humanas. Ela refere-se a valores, bens e normas implicadas no intercâmbio entre humanos. As realidades naturais recebem consideração moral, enquanto respondem a interesses humanos. Elas só recebem uma atenção moral indireta, por si não merecem ponderação moral. A ética ecológica pretende ampliar essa abrangência, incluindo a biosfera, a natureza, os seres vivos como merecedores de consideração moral por si mesmos e não apenas enquanto servem a interesses humanos.

2. O objeto moral da ética ecológica é a vida em seu sentido mais amplo. A vida é o milagre da natureza diante do qual os humanos devem mostrar admiração e respeito. A vida é fruto de um processo evolutivo de milhões de anos e se reproduz continuamente com a colaboração de fatores abióticos e bióticos que estão em equilibrio nos ecossistemas. A própria vida cria as condições para que ela possa reproduzir-se. A biosfera é uma expressão desse amplo sistema vivente da terra. A terra como um todo pulsa com vida e torna possível a reprodução da vida. Os ecossistemas ou as comunidades bióticas são os nichos regionais de acondicionamento para que a vida em sua variedade possa existir.

3. A vida não pode ser reduzida a uma pura realidade biológica bruta e isolada. Ela é essencialmente dinamismo vital, fluindo como fluxos energéticos entre os seres vivos de um nicho ecológico. A vida depende de processos interdependentes e interrelacionados que estão em equilíbrio. Assim a vida de cada ser vivo não é uma realidade auto-suficiente que se basta a si mesmo. Ela depende de diferentes fatores que possibilitam a sua reedição. A vida não se reproduz na auto-suficiência. Ela necessita colaboração e cooperação para que existam as condições viáveis de sua existência. Por não ser auto-suficiente, a vida é essencialmente frágil e vulnerável. Nisso consiste justamente o seu milagre. Apesar da sua vulnerabilidade, a vida teima em subsistir em sua exuberância e variedade. 
4. A única atitude humana condizente frente à fragilidade da vida é o cuidado que supera a pura perspectiva da justiça e dos direitos. O sujeito moral da ética ecológica precisa desenvolver o modo de ser do cuidado que corrige e completa o modo de ser do trabalho que intervém na natureza para satisfazer necessidades humanas básicas. O ser humano é o único ser que exerce um confronto cultural com seu meio ambiente natural. Nos últimos séculos predominou o confronto cultural do trabalho que trouxe benefícios para a humanidade, mas também efeitos catastróficos para o entorno humano. Por isso, impõe-se a urgência do confronto do cuidado em relação à natureza que tenta preservar o equilibrio dos fatores que possibilitam a reprodução da vida.

5. Para que se fortaleça o modo de ser do cuidado é necessário uma mutação gestáltica do ser humano moderno. Trata-se de superar o modelo "prometeico" que se sobrepõe orgulhosamente aos outros seres vivos e sente-se em total autonomia frente $e$ acima da natureza reduzida a objeto de manipulação. Para que o cuidado torne-se uma atitude básica, o ser humano precisa entender-se inserido e integrado na natureza, dependente dos mesmos fatores que possibilitam a vida dos outros viventes. No momento em que se sentir fazendo parte integrante de um todo maior, a biosfera, dependendo do seu entorno natural e social, se dará conta da sua não auto-suficiência e conseqüente vulnerabilidade. A fragilidade como característica humana foi esquecida pela predominância do modo de ser do trabalho, agigantado pelas possibilidades abertas pela ciência e a técnica. É preciso recuperar essa constante antropológica para uma compreensão do ser humano adequada ao paradigma ecológico. Consciente da própria vulnerabilidade e da necessidade de ser cuidado, ele terá condições de abrir os olhos ao seu entorno ambiental, constatando a fragilidade do equilíbrio vital e assumindo o cuidado como modo de relacionar-se com a natureza.

6. O nível de consciência da indigência da condição humana e da correspondente necessidade da atitude de cuidado dependerá do modo como o ser humano se posiciona diante daqueles que são a expressão visivel da vulnerabilidade humana: os pobres, os necessitados, os abandonados da sua sociedade. Sem assumir uma atitude de solidariedade com aqueles que sofrem o infortúnio e estão ao relento da história, não existe o modo de ser do cuidado perante a vida. Quem não está aberto a ouvir o grito dos pobres, não terá condições de auscultar o grito da natureza, porque falta sensibilidade pelo gemido do pulsar da vida. $O$ 
cuidado solitário pelos deserdados humanos educa e sensibiliza pelo cuidado respeitoso de todo ser vivo. A degradação da face da terra em sua biosfera e nas formas de vida que a povoam é o reverso da medalha do aviltamento do rosto de seres humanos reduzidos à pura sobrevivência.

7. Tendo o cuidado como modo de relacionar-se com a natureza e atitude básica da ética ecológica, o modelo normativo ou utilitarista não é adequado para construir o discurso ético. $\mathrm{O}$ cuidado não pode ser transformado em normas nem ser fruto de um cálculo de benefícios. Ele só será ecologicamente eficiente se tornar-se um modo de estar do próprio ser humano. A sensibilidade cuidadosa pela vida precisa impregnar a personalidade moral das pessoas e manifestar-se como atitude pessoal, constituindo-se como cultura ética da sociedade e tendo assim força para fazer frente à atual crise ecológica e social. Portanto, o modelo de estruturação da ética ecológica só pode ser o da ética do caráter, da personalidade ou o que tradicionalmente se chamou de ética da virtude, em sua expressão pessoal e sociocultural.

8. Mesmo assim a ética ecológica necessita de normas e leis. A atitude de cuidado pela vida precisa estar atenta às normas que regem os ecossistemas e as comunidades bióticas para que o seu equilíbrio vital seja preservado. A ética ecológica necessita estar em contínuo diálogo com a ciência da ecologia que fornece dados a serem levados em consideração, quando existe um confronto cultural com a natureza, uma intervenção no meio ambiente. Portanto, as prescrições éticas são as leis naturais da ecologia. Essas normas necessitam de um respaldo jurídico através de um direito ecológico que determina os limites da intervenção no meio ambiente natural, coibe abusos e aplica sanções.

\section{Conclusão}

O artigo foi uma tentativa de sair do impasse entre antropocentrismo e biocentrismo na discussão da ética ecológica. Não se trata de uma alternativa, mas de uma compenetração. Enquanto ética ela não pode deixar de ser antropocêntrica, porque o sujeito moral da ética é o ser humano como agente moral. Só o ser humano levanta questões éticas e constrói discursos éticos. Não podemos fugir do "princípio antropotópico" da ética.

Mas, enquanto ecológica, a ética necessita ser biocêntrica, porque o seu objeto central de consideração moral é a vida em suas 
inter-relações. Nesse sentido a natureza é merecedora de consideração moral não só enquanto serve a interesses humanos, mas em si mesma por ser a matriz da vida. A ética ecológica é a primeira tentativa de alargar a abrangência da consideração moral para além dos humanos.

José Roque Junges SJ - Doutor em Teologia Moral pela Pontificia Universidade Gregoriana de Roma com tese defendida em 1985. Professor de Moral fundamental, Bioética, ética sexual e matrimonial na Faculdade de Teologia do Centro de Estudos Superiores da Companhia de Jesus em Belo Horizonte. É membro da Sociedade Brasileira de Teologia Moral (SBTM) e da Sociedade Brasiliera de Bioética (SBB). Publicou Bioética: Perspectivas e Desafios, São Leopoldo: Ed. Unisinos, 2000, e Ecologia e Criação: resposta cristã à crise ambiental, São Paulo: Ed. Loyola, 2001.

Endereço: Av. Dr. Cristiano Guimarães 2127 - Planalto 31720-300 - Belo Horizonte - MG e-mail: roquejunges@hotmail.com. 